\title{
RESEARCH
}

Open Access

\section{Nutritional and chemical evaluation of dried pomegranate (Punica granatum L.) peels and studying the impact of level of inclusion in ration formulation on productive performance of growing Ossimi lambs}

Hamed A. A. Omer, Soha S. Abdel-Magid*i( ) and Ibrahim M. Awadalla

\begin{abstract}
Background: By 2050, the world will need to feed an additional 2 billion people and require $70 \%$ more meat and milk. The increasing future demand for livestock products, driven by increases in income, population, and urbanization will impose a huge demand on feed resources. A huge quantity of fruit and vegetable wastes and byproducts from the fruit and vegetable processing industry are available throughout the world that encourages to using it as a new source feeds in animal ration formulation.

Methods: Twenty-eight male growing Ossimi lambs used to study the impact of inclusion dried pomegranate peels (DPP) on productive performance and economic efficiency. In nutritional and chemical evaluation conducted, amino acids, minerals, vitamins, polyphenolic, and fatty acid compositions were determined. Experimental lambs were allocated to one of four complete feed mixture (CFM) containing 0, 0.50, 1.00, and 2.00\% DPP for (CFM 1 , $\mathrm{CFM}_{2}, \mathrm{CFM}_{3}$, and $\left(\mathrm{CF}_{4}\right)$, respectively throughout the feeding period that continuous for 119 days. Twenty-eight lambs with aged 5-6 months with initial weight of $22.875 \pm 0.38 \mathrm{~kg}$ were divided into four equal groups, each of 7 lambs and fed one of the four iso-nitrogenous that contains $17.1 \% \mathrm{CP}$ and iso-energetic that contained 2.76\% of ether extract (EE) and gross energy (GE) ranged from 4212 to $4214 \mathrm{kcal} / \mathrm{kg} \mathrm{DM}$.

* Correspondence: Soha_Syd@yahoo.com

Animal Production Department, National Research Centre, 33 El-Bohouth

Street, P.O: 12622, Dokki, Cairo, Egypt 
(Continued from previous page)

Results: Dried pomegranate peel superior in their contents of crude fiber (CF), ether extract (EE), ash, and lignin in comparison with yellow corn. Meanwhile, yellow corn was superior in CP, nitrogen-free extract (NFE), neutral detergent fiber (NDF), acid detergent fiber (ADF), hemicellulose, cellulose, and GE contents in comparison with dried pomegranate peel. Total essential amino acid value was recorded at $51.30 \mathrm{~g} / 100 \mathrm{~g} \mathrm{CP}$; meanwhile, value of non-essential amino acids was recorded at $48.37 \mathrm{~g} / 100 \mathrm{~g}$ CP. The DPP contained 342, 120, 150, 68, and 56 mg/100 g of calcium (Ca), phosphorus (P), potassium (K), sodium (Na), and magnesium (Mg), respectively. Meanwhile, it contains 1.08, 0.86, 0.65, 6.11, and $1.07 \mathrm{mg} / 100 \mathrm{~g}$ of zinc (Zn), manganese (Mn), cobber (Cu), iron (Fe), and selenium (Se), respectively. Moreover, vitamins were determined by 0.141, 0.09, 13.26, 4.13, and $0.181 \mathrm{mg} / 100 \mathrm{~g}$ for vit. $\mathrm{B}_{1}$; vit. $B_{2}$; vit. $C$; vit. $E$; and vit. A, respectively. Dried pomegranate peel contains high percentages of unsaturated fatty acids that evaluated by $76.96 \%$, while saturated fatty acids (SFA) recorded $23.04 \%$. DPP contained $1.4404 \%$ of total polyphenols. Final weight, total body weight gain, and average daily gain were improved. Dry matter intake was significantly $(P<0.05)$ decreased when expressed as $\mathrm{g} / \mathrm{h} / \mathrm{d}$ and $\mathrm{g} / \mathrm{kgW}^{0.75}$, while feed conversion insignificantly $(P>$ 0.05) improved. Dietary treatment improved relative economical efficiency by 117.1, 130.3, and 109\% compared with control one with considered control ration equals 100\%. Feed cost (LE/kg gain) was decreased.

Conclusion: From this study, it could be mentioned that dried pomegranate peels can be used safely in animal feeding at level of $1 \%$ because this level realized the best growth performance and depressed the price of ration cost and recorded the best relative economical efficiency.

Keywords: Pomegranate peels, Lambs, Growth performance, Economic evaluation,

\section{Background}

Agro industrial by-products which contain little economical value as edible foods for human consumption have become major sources of dietary nutrients and energy in support of milk and meat production and will continue to do so in the future (Bampidis and Robinson 2006).

Pomegranate fruit has been cultivated around the world in subtropical and tropical regions such as in Iraq, Iran, California, Turkey, Egypt, Italy, India, Chile, and Spain (Sadq et al. 2016).

Pomegranate production amounts could reach to approximately 65,000 tons in Egypt (FAOSTAT-FAO 2010), where the peels (pericarp, rind, or hull) amount to approximately $60 \%$ of the pomegranate fruit weight (Lansky and Newman 2007). On the other hand, it is noticed that, about $500 \mathrm{~g} / \mathrm{kg}$ of the total fruit weight corresponds to the peel, while the rest are the edible parts of pomegranate, consisting of $400 \mathrm{~g} / \mathrm{kg}$ arils and $100 \mathrm{~g} / \mathrm{kg}$ seeds (Aviram et al. 2000).

Recently, pomegranate by-products have attracted attention, as they have been found to contain substantial amounts of polyphenols such as ellagic tannins, ellagic acid, punicalagin, and gallic acid (Jami et al. 2012), which have been shown to possess antimicrobial, antioxidant, antiinflammatory, antimitotic, and immunomodulatory properties both in vivo and in vitro (Adams et al. 2006; Jayaprakasha et al. 2006; Rosenblat and Aviram 2006; Kotsampasi et al. 2014).

Pomegranate is an important source of bioactive compounds and different parts of it have been used in medicine for many centuries (Hajimahmoodi et al. 2008;
Elfalleh et al. 2012; Hajimahmoodi et al. 2013) and the edible parts used pharmaceutical world-wide.

Pomegranate is composed of a rich variety of flavonoids, which comprise approximately 0.2 to $1.0 \%$ of the fruit. Approximately $30 \%$ of all anthocyanidins found in pomegranate are contained within the peel. These flavonoid-rich pomegranate phenolic fractions are responsible for anticancer activity (Batta 1973; Elango et al. 2011).

Pomegranate peel provides higher yields of phenolics, flavonoids, and proanthocyanidins than the pulp. Flavonoid content was significantly greater in the peel than the pulp (59 vs. $17 \mathrm{mg} / \mathrm{g}$ ), as were proanthocyanidins (11 vs. $5 \mathrm{mg} / \mathrm{g}$ ) as reported by (Li et al. 2006).

There are some reports about the presence of tannins, alkaloids, glycosides, flavonoids, and phenolic compounds as antioxidant factors in juice, peel, pulp, and seed fractions of pomegranate (Noda et al. 2002).

Pomegranate (mainly pulp) may play a role in the prevention of cancer and heart disease (Aviram et al. 2002).

Sadq et al. (2016) noted that incorporation pomegranate peels at different levels $(0,1,2$, or $4 \%)$ in Karadi lamb rations improved their growth performance.

Also, Shabtay et al. (2008) reported that dietary supplementation with fresh pomegranate peels promoted a significant increase in feed intake, with a positive tendency toward increased body weight gain in bull calves.

So, this work was carried out to investigate the nutritional and chemical evaluation of dried pomegranate peels, in addition to study the impact of inclusion pomegranate peel in growing Ossimi lamb rations at 
different levels on their performance and economic evaluation.

\section{Methods}

The present experiment was carried out at the Sheep and Goats' Units in El-Bostan area in Nubaria, which belongs to the Animal Production Department, National Research Center, Dokki, Cairo, Egypt.

Twenty-eight male Ossimi lambs, aged 5-6 months old with an average live weight of $22.875 \pm 0.38 \mathrm{~kg}$, were divided randomly into four equal groups (seven animals each) to study the effect of incorporation dried pomegranate (Punica granatum L.) peels (DPP) at different levels $(0,0.5,1.0$, and $2.0 \%)$ on growth performance and economic evaluation.

Experimental animals were housed in semi-open pens and fed as group feeding for 119 days, the experimental rations received to cover the requirements of total digestible nutrients and protein for growing sheep according to the NRC (1985).

Pomegranate (Punica granatum L.; Punicaceae) peels were obtained from Vitrac company for food industrials. The peel was sun-dried, powdered, and incorporated in experimental complete feed mixture (CFM) at levels of $0.00,0.50,1.00$, and $2.00 \%$ for $\left(\mathrm{CFM}_{1}, \mathrm{CFM}_{2}, \mathrm{CFM}_{3}\right.$, and $\mathrm{CFM}_{4}$ ), respectively.

Daily amounts of experimental CFM were adjusted every 2 weeks according to body weight changes. Total mixed rations were offered twice daily in two equal portions at 800 and $1300 \mathrm{~h}$, while feed residues were daily collected, sun dried, and weekly weighed. Fresh water was freely available at all times in plastic containers. Body weight change was weekly recorded before the morning meal.

\section{Analytical procedures}

Representative samples of experimental TMR were analyzed according to AOAC (2005) methods.

Amino acid composition of dried pomegranate peels (DPP) was determined according to the method described by the AOAC (2005) and Millipore Cooperative (1987) using HPLC and the modification of PICO-TAG methods.

Mineral were determined by digested a part of sample in $10 \mathrm{ml}$ of nitric acid overnight on a steam bath and subsequently digested with $70 \%$ perchloric acid. Calcium, $\mathrm{P}, \mathrm{K}, \mathrm{Na}, \mathrm{Mg}, \mathrm{Zn}, \mathrm{Mn}, \mathrm{Cu}, \mathrm{Fe}$, and Se were analyzed by atomic absorption spectrophotometry using standard procedures of the AOAC (2005). Phosphorus was analyzed using method N-4C according to (Kraul 1966). Meanwhile, selenium was determined with an autoanalyzer fluorometric selenium method described by Brown and Watkinson (1977).
Fatty acid profiles were conducted throughout extracted lipids from DPP by diethyl ether as described by the AOAC (2005). The extracted lipids were converted to methyl esters as described by AOAC (2000) and analyzed for individual fatty acids (C14: 0 to C20: 4) using a gas chromatograph (3400, Varian Inc., Walnut Creek, CA) fitted with a flame ionization detector. Gas chromatography parameters were as follows: the column temperature was $50^{\circ} \mathrm{C}$ for $3 \mathrm{~min}$ and then increased to $220^{\circ} \mathrm{C}$ at $4{ }^{\circ} \mathrm{C} / \mathrm{min}$ and was held for $15 \mathrm{~min}$. The injector temperature was $200^{\circ} \mathrm{C}$, and the detector temperature was $250{ }^{\circ} \mathrm{C}$. The flow rates of the carrier gases (hydrogen and oxygen) were 30 and $300 \mathrm{ml} / \mathrm{min}$, respectively. Identification and quantification of individual fatty acids were made by using a standard fatty acid methyl ester mixture (2010, Matreya Biochemical LLC, Pleasant Gap, PA).

Vitamins including $B_{1}$ (Thiamin), $B_{2}$ (riboflavin), and $C$ (L-Ascorbic) of DPP were evaluated according to the method described in the AOAC (2005) using highperformance liquid chromatography (HPLC), while both vitamin $E(\alpha$-Tochoferol) and vitamin A (Retinol) were determined using high-pressure liquid chromatography (HPLC) method that described by (Leth and Sondergaro 1983).

The phenolic compounds of DPP were extracted according to the method of Singleton et al. (1999) in which a known weight $(0.5 \mathrm{~g})$ of dried DPP was extracted with $50 \mathrm{ml}$ methanol for $3 \mathrm{~h}$. Identification of individual phenolic compounds of investigated DPP was performed on a HPLC.

\section{Economic evaluation}

Economic evaluation was done using the relationship between feed costs (local market price of ingredients) and sheep live body weight gain. Economic evaluation was calculated as follows:

The cost for $1-\mathrm{kg}$ gain $=$ total cost Egyptian pound (LE)\} of feed intake/total gain (kilogram).

\section{Statistical analysis}

Collected data of feed intake, live body weight, average daily gain, and feed conversion were subjected to statistical analysis as one-way analysis of variance using the general linear model procedure of SPSS (2008). Duncan's Multiple Range Test (1955) was used to separate means when the dietary treatment effect was significant according to the following model:

$Y_{i j}=\mu+T_{i}+e_{i j}$. Where $Y_{i j}=$ observation, $\mu=$ overall mean, $T_{i}=$ effect of tested complete feed mixture (CFM) containing different levels of dried pomegranate peels (DPP) for $i=1-4,1=$ CFM contained 0\% DPP, $2=$ CFM contained $0.50 \%$ DPP, $3=$ CFM contained $1.00 \%$ DPP, and $4=$ CFM contained $2.00 \%$ DPP.

$e_{i j}=$ the experimental error. 
Table 1 Chemical analysis of yellow corn and dried pomegranate peel

\begin{tabular}{|c|c|c|}
\hline Item & $\begin{array}{l}\text { Yellow } \\
\text { corn }\end{array}$ & $\begin{array}{l}\text { Dried pomegranate peel } \\
\text { (DPP) }\end{array}$ \\
\hline Moisture & 9.78 & 9.85 \\
\hline \multicolumn{3}{|c|}{ Chemical analysis (\%) on DM basis } \\
\hline Organic matter (OM) & 97.43 & 96.57 \\
\hline Crude protein (CP) & 8.85 & 6.52 \\
\hline Crude fiber (CF) & 4.80 & 10.50 \\
\hline Ether extract (EE) & 3.30 & 3.46 \\
\hline Nitrogen free extract (NFE) & 80.48 & 76.09 \\
\hline Ash & 2.57 & 3.43 \\
\hline \multicolumn{3}{|l|}{ Cell wall constituents } \\
\hline $\begin{array}{l}\text { Neutral detergent fiber } \\
\text { (NDF) }\end{array}$ & 37.14 & 29.36 \\
\hline Acid detergent fiber (ADF) & 23.65 & 19.22 \\
\hline $\begin{array}{l}\text { Acid detergent lignin } \\
\text { (ADL) }\end{array}$ & 2.18 & 3.90 \\
\hline Hemicellulose $^{a}$ & 13.49 & 10.14 \\
\hline Cellulose ${ }^{b}$ & 21.47 & 15.32 \\
\hline Gross energy (kcal/kg DM) & 4349 & 4287 \\
\hline
\end{tabular}

${ }^{\mathrm{a}}$ Hemicellulose $=$ NDF - ADF ${ }^{\mathrm{b}}$ Cellulose $=$ ADF - ADL

Gross energy (kcal/kg DM) was calculated according to Blaxter (1968). Each $\mathrm{g}$ $\mathrm{CP}=5.65 \mathrm{kcal}, \mathrm{g} \mathrm{EE}=9.40 \mathrm{kcal}$, and $\mathrm{g}(\mathrm{CF} \& \mathrm{NFE})=4.15 \mathrm{kcal}$

\section{Results}

Nutritional and chemical evaluation of dried

pomegranate peels

\section{Chemical analysis}

Data of Table 1 cleared that dried pomegranate peel (DPP) superior in their contents of CF, EE, ash, and lignin compared with yellow corn. Meanwhile, yellow corn was superior in $\mathrm{CP}, \mathrm{NFE}, \mathrm{NDF}, \mathrm{ADF}$, hemicellulose, cellulose, and gross energy contents in comparison with dried pomegranate peels. The present results mentioned that chemical composition of DPP near from yellow corn, so it can be using DPP as unconventional source of energy in sheep ration formulation. The corresponding values were (8.85 vs. $6.52 \mathrm{CP})$; (4.80 vs. $10.50 \mathrm{CF})$; (3.30 vs. $3.46 \mathrm{EE})$; (80.48 vs. $76.09 \mathrm{NFE})$; (2.57 vs. 3.43 ash); (37.14 vs. $29.36 \mathrm{NDF}) ;(23.65$ vs. $19.22 \mathrm{ADF}) ;(2.18$ vs. $3.90 \mathrm{ADL})$; (13.49 vs. 10.14 hemicellulose); (21.47 vs. 15.32 cellulose); and (4349 vs. $4287 \mathrm{kcal} / \mathrm{kg}$ dry matter for gross energy) for yellow corn and dried pomegranate peel, respectively.

\section{Amino acid composition}

Amino acid composition of dried pomegranate peels ( $\mathrm{g} /$ $100 \mathrm{~g} \mathrm{CP}$ ) that illustrated in (Table 2) cleared that DPP protein contained a much higher content of essential amino acids (arginin, histidine, leucine, lysine, phenylalanine, and valine). The corresponding values were 8.23, 7.56; 7.16, 7.23, 7.14, and 5.33 (g/100 g CP) for the
Table 2 Amino acid composition of dried pomegranate peels (g/100 g CP)

\begin{tabular}{ll}
\hline Item & Amino acid g/100 g CP) \\
\hline Essential amino acids & 8.23 \\
Arginine & 7.56 \\
Histidine & 3.51 \\
Isoleucine & 7.16 \\
Leucine & 7.23 \\
Lysine & 3.02 \\
Methionine & 7.14 \\
Phenylalanine & 2.12 \\
Thronine & 5.33 \\
Valine & 51.30 \\
Subtotal & \\
Nonessential amino acids & 5.05 \\
Alanine & 8.11 \\
Aspartic & 1.02 \\
Cystine & 13.52 \\
Glutamic & 12.41 \\
Glycine & 3.22 \\
Proline & 3.02 \\
Serine & 2.02 \\
Tyrosine & 48.37 \\
Subtotal & 0.33 \\
Not determined & 100 \\
Total & \\
\hline
\end{tabular}

same amino acids, respectively. On the other hand, both isoleucine and methionine recorded the moderate values (3.51 and $3.02 \mathrm{~g} / 100 \mathrm{~g} \mathrm{CP}$, respectively); meanwhile, thronine showed the lowest value $(2.12 \mathrm{~g} / 100 \mathrm{~g} \mathrm{CP})$. Essential amino acids recorded $(51.30 \mathrm{~g} / 100 \mathrm{~g} \mathrm{CP})$ of total amino acid in DPP, while non-essential amino acids (alanine, aspartic, cystine, glutamic, glycine, praline, serine, and tyrosine) recorded (48.37 g/100 g CP).

\section{Minerals content}

Determination of mineral content of dried pomegranate peel (DPP) that presented in Table 3 showed that DPP contained all tested minerals. The DPP contained the most determined minerals at adequate concentration and the predominant minerals in DPP were found to be $\mathrm{Ca}, \mathrm{P}, \mathrm{K}, \mathrm{Na}$, and $\mathrm{Mg}$ at levels of $342,120,150,68$, and $56 \mathrm{mg} / 100 \mathrm{~g} \mathrm{DM}$, respectively. In addition, the DPP contained a considerable content of $\mathrm{Zn}, \mathrm{Mn}, \mathrm{Cu}, \mathrm{Fe}$, and $\mathrm{Se}$ at levels of 1.08, 0.86, 0.65, 6.11, and $1.07 \mathrm{mg} / 100 \mathrm{~g} \mathrm{DM}$, respectively. So, in general, the present results can be concluded that DPP were characterized with their richness with the most determined nutritious minerals and they are considered a good source of macro- and micro- 
Table 3 Mineral content of dried pomegranate peels $(\mathrm{mg} / 100$

\begin{tabular}{lll} 
g) & & \\
\hline Item & & \\
\hline Macro-elements & & 342 \\
Calcium & $(\mathrm{Ca})$ & 120 \\
Phosphorus & $(\mathrm{P})$ & 150 \\
Potassium & $(\mathrm{K})$ & 68 \\
Sodium & $(\mathrm{Na})$ & 56 \\
Magnesium & $(\mathrm{Mg})$ & \\
Micro-elements & & 1.08 \\
Zinc & $(\mathrm{Zn})$ & 0.86 \\
Manganese & $(\mathrm{Mn})$ & 0.65 \\
Cupper & $(\mathrm{Cu})$ & 6.11 \\
Iron & $(\mathrm{Fe})$ & 1.07 \\
Selenium & $(\mathrm{Se})$ &
\end{tabular}

elements. Therefore, they should be utilized in food fortification.

\section{Vitamin contents}

Data of Table 4 included the vitamins that determined in DPP that composed of vit. $B_{1}$ (Thiamine), vit. $B_{2}$ (Riboflavin), vit. C (L-Ascorbic acid), vit. E ( $\alpha$-Tochoferol), and vit. A (Retinol). The corresponding values of vitamins determined above were $0.141 ; 0.09,13.26,4.13$, and $0.181 \mathrm{mg} / 100 \mathrm{~g}$ DM of DPP.

\section{Fatty acid profile}

Data of fatty acid profile that illustrated in Table 5 cleared that DPP contains high percentages of unsaturated fatty acids $\{\omega-9$ cis-9 Oleic (C18: 1$) ; \omega-6$ cis-9,12 linoleic (C18: 2); $\omega-3$ cis-9, 12, $15 \alpha$-linolenic acid (C18: 3); $\omega-3$ cis-4, 7, 10, 13, 16, 19 eicosapentaenoic acid (C20: 5); and $\omega-3$ cis-4, 7, 10, 13, 16, 19 docosahexaenoic acids\}. The corresponding values were 10.95, 13.89, 6.03, 12.23 , and $17.22 \%$, respectively. Total unsaturated fatty acids (TUFA) recorded $76.96 \%$, while saturated fatty acids (SFA) recorded $23.04 \%$. On the other hand, $\omega 3$ fatty acid value was $35.48 \%$; meanwhile, $\omega 6$ fatty acid value was $20.72 \%$ and $\omega 9$ fatty acid value was $17.64 \%$.

\section{Polyphenolic fraction contents}

Data of polyphenolic fraction content of DPP is presented in Table 6. The obtained results showed that DPP contained a high content $(1440.40 \mathrm{mg} / 100 \mathrm{~g}$ DDP) that equals $(1.4404 \%)$ of total polyphenols. The major polyphenolic fractions in DPP were catechins, phenol, gallic acid, caffeic acid, ellagic acid, p-coumaric acid, and resocenol which were found at the level of 892, 254.36, $128,55.23,52.03,14.22$, and $14.09 \mathrm{mg} / 100 \mathrm{~g}$ DM of DPP, respectively. On the other hand, DPP also contained adequate amounts from protocatechol, $p$-hydroxy benzoic
Table 4 Vitamin content (mg/100 g) of dried pomegranate peel

\begin{tabular}{ll}
\hline Vitamins content & $\mathrm{mg} / 100 \mathrm{~g}$ \\
\hline B1 (Thiamine) & 0.141 \\
B2 (Riboflavin) & 0.09 \\
C (L-Ascorbic acid) & 13.26 \\
E (a-Tochoferol) & 4.13 \\
A (Retinol) & 0.181 \\
\hline
\end{tabular}

acid, vanilline, and ferulic acid at concentrations of 4.62, $10.33,4.17$, and $6.11 \mathrm{mg} / 100 \mathrm{~g}$ DM of DPP, respectively.

\section{Composition and chemical analysis of complete feed mixture}

Data of Table 7 cleared that different experiment complete feed mixture was formulated as iso-caloric and iso-nitrogenous. Crude protein contents were ranged from 17.07 to $17.12 \%$; ether extract content ranged from 2.75 to $2.76 \%$; and gross energy ranged from 4212 to $4214 \mathrm{kcal} / \mathrm{kg} \mathrm{DM}$; meanwhile, crude fiber varied from 10.90 to $11.01 \%$; nitrogen-free extract ranged from 61.00 to $61.08 \%$; and ash content ranged from 8.14 to $8.16 \%$.

\section{Growth performance}

The present results of growth performance are presented in Table 8 showed that inclusion dried pomegranate peel (DPP) at different levels $(0.5,1.0$, and $2.0 \%)$ in complete feed mixture $\left(\mathrm{CFM}_{2}\right.$ to $\left.\mathrm{CFM}_{4}\right)$ improved final weight, total body weight gain, and average daily gain. These values were improved by $(6.52,10.87$ and $2.17 \%$ for final weight); (10.64, 18.09 and $3.19 \%$ for total body weight gain); and (10.38, 17.97 and $3.29 \%$ for average daily gain) for $\mathrm{CFM}_{2}, \mathrm{CFM}_{3}$, and $\mathrm{CFM}_{4}$, respectively in comparison with the control $\left(\mathrm{CFM}_{1}\right)$. The best values were noticed by $\left(\mathrm{CFM}_{3}\right.$ that contained $\left.1 \% \mathrm{DPP}\right)$.

\section{Economic evaluation}

The profitability of using agro-industrial by-products in ration formulation of livestock depends on upon the costing of tested materials, ingredients used in ration formulations, and the growth performance obtained.

Data of Table 9 cleared that incorporation DPP at different levels in ration formulation slightly decreased price of $1 \mathrm{~kg}$ of CFM; however, dietary treatment improved relative economical efficiency by 117.1, 130.3, and $109 \%$ compared with control one with considered the relative economical efficiency of control ration equals $100 \%$. On the other hand, feed cost (LE/kg gain) was decreased with inclusion DPP in the CFM. The corresponding values of feed cost were 22.98, 20.64, 18.88, and 20.83 (LE/kg gain) for $\mathrm{CFM}_{1}, \mathrm{CFM}_{2}, \mathrm{CFM}_{3}$, and $\mathrm{CFM}_{4}$, respectively. 
Table 5 Fatty acid profile of dried pomegranate peel

\begin{tabular}{|c|c|c|}
\hline Fatty acid profile & & $\%$ \\
\hline $\mathrm{C} 10: 0$ & Capric acid & 1.02 \\
\hline $\mathrm{C} 12: 0$ & Lauric acid & 0.83 \\
\hline C14:0 & Myristic acid & 1.09 \\
\hline C15:0 & Pentadecanoic acid & 2.02 \\
\hline C16:0 & Palmitic acid & 12.44 \\
\hline$C 16: 1 \omega-7$ & $\omega-7$ cis-9 Palmitoleic acid & 3.12 \\
\hline C16:1 $\omega-9$ & $\omega-9$, cis-7 Hexadecenoic acid & 1.65 \\
\hline C17:0 & Margaric acid & 0.75 \\
\hline C18:0 & Stearic acid & 3.72 \\
\hline C18:1 $\omega-9$ & $\omega-9$ cis-9 Oleic acid & 10.95 \\
\hline C18:2 w-6 & $\omega-6$ trans-9,12 Linolelaidic acid & 1.83 \\
\hline$C 18: 2 \omega-6$ & $\omega-6$ cis-9,12 Linoleic acid & 13.89 \\
\hline C18:3 w-3 & $\omega-3$ cis-9, 12, 15 a-linolenic acid & 6.03 \\
\hline C20:1 $\omega-9$ & $\omega-9$ cis-11 Gadoleic acid & 1.44 \\
\hline c20:3 $\omega-6$ & $\omega-6$ cis-8, 11, 14 Eicosatrienoic acid & 1.75 \\
\hline$C 20: 4 \omega-6$ & $\omega-6$ cis- $5,8,11,14$ Arachidonic acid & 3.25 \\
\hline$C 20: 5 \omega-3$ & $\omega-3$ cis-5, 8, 11, 14, 17 Eicosapentaenoic acid (EPA) & 12.23 \\
\hline C21:0 & Heneicosanoic acid & 1.17 \\
\hline$C 22: 6 \omega-3$ & $\omega-3$ cis-4, $7,10,13,16,19$ Docosahexaenoic acid (DHA) & 17.22 \\
\hline$C 24: 1 \omega-9$ & $\omega-9$ cis-15 Nervonic acid & 3.60 \\
\hline \multicolumn{2}{|l|}{ SFA: saturated fatty acids } & 23.04 \\
\hline \multicolumn{2}{|l|}{ MUFA: monounsaturated fatty acids } & 20.76 \\
\hline \multicolumn{2}{|l|}{ PUFA: polyunsaturated fatty acids } & 56.20 \\
\hline \multicolumn{2}{|l|}{$\omega 6$ fatty acids } & 20.72 \\
\hline \multicolumn{2}{|l|}{ w3 fatty acids } & 35.48 \\
\hline \multicolumn{2}{|l|}{$\omega 6 / \omega 3$} & 0.58 \\
\hline \multicolumn{2}{|l|}{$\omega 7$ fatty acids } & 3.12 \\
\hline \multicolumn{2}{|l|}{$\omega 9$ fatty acids } & 17.64 \\
\hline \multicolumn{2}{|l|}{ TUFA: total unsaturated fatty acids } & 76.96 \\
\hline
\end{tabular}

\section{Discussion}

The present results of chemical analysis of dried pomegranate peel that illustrated in Table 1 were in harmony with those noted by Shabtay et al. (2008) and Kushwaha et al. (2013).

Our results obtained in Table 2 cleared that DPP is good quality source of protein that can be used in sheep ration formulation. Added to that, these results in agreement with those noticed by (Rowayshed et al. 2013) who noted that pomegranate fruit by-products (peels and seeds, powder) contained a much higher exceptionally content of lysine, isoleucine, and amino acid-containing sulphur (Methionine and cysteine), which are usually deficient in the most food stuffs, than the reference protein pattern of $\mathrm{FAO} / \mathrm{WHO}$.

Results of mineral content for dried pomegranate peel that presented in (Table 3) were in harmony with those noted by (Rowayshed et al. 2013) who reported that pomegranate fruit by-products were characterized with their richness with the most determined minerals.

Data of Table 4 that illustrated the vitamin contents of DPP cleared that it contained vit. $B_{1}$ (Thiamine), vit. $B_{2}$ (Riboflavin), vit. $\mathrm{C}$ (L-Ascorbic acid), vit. E ( $\alpha$-Tochoferol), and vit. A (Retinol). The result values were in agreement with those established by (Rowayshed et al. 2013). The determination of vitamins naturally occurred in DPP is considered one of the most important phytochemicals having the antioxidant, antimicrobial, and chemo preventive cancer properties and good standpoint in human nutrition (Huxley and Neil 2003). So, it could be mentioned that DPP considered a good source of vitamins.

Data obtained of fatty acid profile that illustrated in Table 5 cleared that DPP can be used as a good quality 
Table 6 Polyphenolic fractions content $(\mathrm{mg} / 100 \mathrm{~g})$ of dried pomegranate peel

\begin{tabular}{ll}
\hline Polyphenolic fractions & $\mathrm{mg} / 100 \mathrm{~g}$ DPP \\
\hline Ellagic acid & 52.03 \\
Catechins & 892.00 \\
Gallic acid & 128.10 \\
Resocenol & 14.09 \\
Protocatechol & 4.62 \\
p-hydroxy benzoic acid & 10.33 \\
Phenol & 254.36 \\
Vanilline & 4.17 \\
Caffeic acid & 55.23 \\
Ferulic acid & 6.11 \\
p-Coumaric acid & 14.22 \\
Others & 5.14 \\
Total & 1440.40 \\
\hline
\end{tabular}

Table 7 Composition and chemical analysis of complete feed mixture

\begin{tabular}{|c|c|c|c|c|c|}
\hline \multirow[t]{2}{*}{ Item } & \multicolumn{4}{|c|}{ Complete feed mixture (CFM) } & \multirow{2}{*}{$\begin{array}{l}\text { Price, L.E/ } \\
\text { ton of } \\
\text { ingredients }\end{array}$} \\
\hline & $\mathrm{CFM}_{1}(0 \% \mathrm{DPP})$ & $\mathrm{CFM}_{2}(0.5 \% \mathrm{DPP})$ & $\mathrm{CFM}_{3}(1 \% \mathrm{DPP})$ & $\mathrm{CFM}_{4}(2 \% \mathrm{DPP})$ & \\
\hline \multicolumn{6}{|l|}{ 1. Composition (kg/ton) } \\
\hline Yellow corn & 350 & 345 & 340 & 330 & 3250 \\
\hline Dried pomegranate peel & - & 5 & 10 & 20 & 3000 \\
\hline Berseem hay & 250 & 250 & 250 & 250 & 2500 \\
\hline Wheat bran & 200 & 200 & 200 & 200 & 2750 \\
\hline Soybean meal & 170 & 170 & 170 & 170 & 6.250 \\
\hline Limestone & 15 & 15 & 15 & 15 & 100 \\
\hline Sodium chloride & 10 & 10 & 10 & 10 & 750 \\
\hline Vit. and Min. mixture ${ }^{a}$ & 5 & 5 & 5 & 5 & 15,000 \\
\hline Price, LE/ton of ingredients & 3459 & 3458 & 3457 & 3454 & \\
\hline \multicolumn{6}{|l|}{ 2. Chemical analysis (\%) } \\
\hline Moisture & 8.92 & 8.92 & 8.93 & 8.93 & \\
\hline \multicolumn{6}{|l|}{ Chemical analysis on DM basis } \\
\hline Organic matter (OM) & 91.86 & 91.85 & 91.86 & 91.84 & \\
\hline Crude protein (CP) & 17.12 & 17.10 & 17.10 & 17.07 & \\
\hline Crude fiber (CF) & 10.90 & 10.93 & 10.96 & 11.01 & \\
\hline Ether extract (EE) & 2.76 & 2.76 & 2.75 & 2.76 & \\
\hline Nitrogen free extract (NFE) & 61.08 & 61.06 & 61.05 & 61.00 & \\
\hline Ash & 8.14 & 8.15 & 8.14 & 8.16 & \\
\hline Gross energy (kcal/kg DM) & 4214 & 4213 & 4213 & 4212 & \\
\hline
\end{tabular}

DPP dried pomegranate peel

${ }^{a}$ Each 3-kg vitamin and mineral mixture contains the following: vitamin A 12,000,000 IU, vitamin $D_{3} 2,200,000 \mathrm{IU}$, vitamin E 10,000 mg, vitamin $\mathrm{K}_{3} 2000 \mathrm{mg}$, vitamin $B_{1} 1000 \mathrm{mg}$, vitamin $B_{2} 5000 \mathrm{mg}$, vitamin $B_{6} 1500 \mathrm{mg}$, vitamin $B_{12} 10 \mathrm{mg}$, pantothenic acid $10 \mathrm{mg}$, niacin $30,000 \mathrm{mg}$, folic acid $1000 \mathrm{mg}$, biotin $50 \mathrm{mg}$, choline $300,000 \mathrm{mg}$, manganese $60,000 \mathrm{mg}$, zinc $50,000 \mathrm{mg}$, copper $10,000 \mathrm{mg}$, iron $30,000 \mathrm{mg}$, iodine $100 \mathrm{mg}$, selenium $100 \mathrm{mg}$, cobalt $100 \mathrm{mg}$, CaCo3 to $3000 \mathrm{~g}$

of fatty acids in sheep ration formulation. In addition, the present results were in agreement with those found by (Kotsampasi et al. 2014).

Polyphenolic fraction contents of DPP that presented in Table 6 are nearly in accordance with those obtained by Metche et al. (1996); Wang et al. (2004a, 2004b); Abbasi et al. (2008a, 2008b); Elfalleh et al. (2011); AbdelRahim et al. (2013) and Rowayshed et al. (2013).

Data of Table 7 showed that different experiment complete feed mixture was formulated as iso-caloric and iso-nitrogenous and their chemical analysis was covered the nutrient requirement for sheep according to NRC (1985).

Results of growth performance that illustrated in Table 8 recorded that when DPP incorporated at different levels $(0.5,1$, and $2 \%)$, it caused an improvement in their gain while decreasing their feed intake and improving their feed conversion. These results in agreement with those reported by Sadq et al. (2016) who showed that final body weight was significantly $(P<0.05)$ higher in Karadi lambs fed $1 \%$ or $2 \%$ pomegranate peel as compared with lambs fed 4\%. Also, incorporation DPP at level of 1 or $2 \%$ significantly $(P<0.05)$ decreased dry matter intake as expressed as $\mathrm{g} / \mathrm{h} / \mathrm{d}$ or $\mathrm{g} / \mathrm{kgW}^{0.75}$; 
Table 8 Growth performance of experimental groups

\begin{tabular}{|c|c|c|c|c|c|}
\hline \multirow[t]{2}{*}{ Item } & \multicolumn{5}{|c|}{ Complete feed mixture (CFM) } \\
\hline & $\mathrm{CFM}_{1}(0 \% \mathrm{DPP})$ & $\mathrm{CFM}_{2}(0.5 \% \mathrm{DPP})$ & $\mathrm{CFM}_{3}(1 \% \mathrm{DPP})$ & $\mathrm{CFM}_{4}(2 \% \mathrm{DPP})$ & SEM \\
\hline \multicolumn{6}{|l|}{ Live body weight (LBW) } \\
\hline No. of animals & 7 & 7 & 7 & 7 & - \\
\hline Initial weight (kg) & 22.50 & 23.00 & 23.25 & 22.75 & 0.38 \\
\hline Final weight (FW, kg) & $46.00^{b}$ & $49.00^{\mathrm{ab}}$ & $51.00^{\mathrm{a}}$ & $47.00^{\mathrm{b}}$ & 0.63 \\
\hline Total body weight gain (TBWG, kg) & $23.50^{c}$ & $26.00^{\mathrm{ab}}$ & $27.75^{\mathrm{a}}$ & $24.25^{\mathrm{bc}}$ & 0.51 \\
\hline Experimental duration, days & 119 & & & & - \\
\hline Average daily gain (ADG, g/day) & $197.5^{\mathrm{b}}$ & $218^{\mathrm{ab}}$ & $233^{\mathrm{a}}$ & $204^{b}$ & 4.29 \\
\hline Average body weight $(\mathrm{kg})^{\mathrm{d}}$ & $34.25^{\mathrm{b}}$ & $36.00^{\mathrm{ab}}$ & $37.13^{\mathrm{a}}$ & $34.88^{\mathrm{ab}}$ & 0.45 \\
\hline Metabolic body weight size $\left(\mathrm{kgW}^{0.75}\right)$ & $14.16^{\mathrm{b}}$ & $14.70^{\mathrm{ab}}$ & $15.04^{\mathrm{a}}$ & $14.35^{\mathrm{ab}}$ & 0.14 \\
\hline \multicolumn{6}{|l|}{ Feed intake } \\
\hline \multicolumn{6}{|l|}{ Dry matter intake (DMI) } \\
\hline $\mathrm{g} / \mathrm{h} / \mathrm{d}$ & $1199^{a}$ & $1185^{\mathrm{ab}}$ & $1160^{b}$ & $1121^{\mathrm{b}}$ & 13.85 \\
\hline $\mathrm{g} / \mathrm{kgWW}^{0.75}$ & $84.68^{\mathrm{a}}$ & $80.61^{\mathrm{ab}}$ & $77.13^{b}$ & $78.12^{\mathrm{b}}$ & 0.26 \\
\hline $\mathrm{Kg} / 100 \mathrm{~kg}$ LBW & $3.501^{\mathrm{a}}$ & $3.292^{\mathrm{ab}}$ & $3.124^{b}$ & $3.214^{\mathrm{ab}}$ & 0.02 \\
\hline \multicolumn{6}{|l|}{ Feed conversion (g intake/g gain) of: } \\
\hline Dry matter (DM) & 6.07 & 5.44 & 4.98 & 5.50 & 0.08 \\
\hline
\end{tabular}

$\mathrm{a}, \mathrm{b}, \mathrm{c}$ Means in the same row having different superscripts differ significantly $(P<0.05)$ SEM standard error of mean

${ }^{\mathrm{d}}$ Average body weight $=($ Initial weight + Final weight/2). DPP dried pomegranate peels

however, $\mathrm{CFM}_{2}$ that contained $0.5 \%$ DPP insignificantly $(P<0.05)$ decreased compared with the control one. These results are in agreement with those found by Reed (1995) and Kushwaha et al. (2013) who noted that high concentration of tannin in pomegranate peel powder may reduce intake, through their negative effect on palatability. In contrast Sadq et al. (2016) found that total dry matter intake increased $(P<0.05)$ significantly in lambs fed $1 \%$ pomegranate peel. On the other hand, dietary treatments insignificantly $(P>0.05)$ improved feed conversion that expressed as (g intake/g gain). The best feed conversion was found with incorporation DPP at $1 \%$ of TMR content (4.98). The present results are in harmony with those reported by Sadq et al. (2016) who established that the best improvements in feed conversion in Karadi lambs fed 1\% pomegranate peels.

Data of economic evaluation (Table 9) mentioned that incorporation DPP in sheep ration formulation realized an improvement in their relative economic efficiency and decreased the feed costing per $\mathrm{kg}$ gain. These results were in agreement with those found by Denek and Can (2006); Omer and Abdel-Magid Soha (2015) who noted

Table 9 Economic evaluation of experimental groups

\begin{tabular}{|c|c|c|c|c|}
\hline \multirow[t]{2}{*}{ Item } & \multicolumn{4}{|c|}{ Complete feed mixture (CFM) } \\
\hline & $\mathrm{CFM}_{1}(0 \% \mathrm{DPP})$ & $\mathrm{CFM}_{2}(0.5 \% \mathrm{DPP})$ & $\mathrm{CFM}_{3}(1 \% \mathrm{DPP})$ & $\mathrm{CFM}_{4}(2 \% \mathrm{DPP}$ \\
\hline Daily feed intake (fresh, kg) & 1.316 & 1.301 & 1.274 & 1.230 \\
\hline Price of $1 \mathrm{~kg}$ of CFM & 3.459 & 3.458 & 3.457 & 3.454 \\
\hline Daily feeding cost (LE) ${ }^{a}$ & 4.55 & 4.50 & 4.40 & 4.25 \\
\hline Average daily gain (kg) & 0.198 & 0.218 & 0.233 & 0.204 \\
\hline Value of daily gain $(L E)^{b}$ & 11.88 & 13.08 & 13.98 & 12.24 \\
\hline Daily profit above feeding cost (LE) & 7.33 & 8.58 & 9.58 & 7.99 \\
\hline Relative economical efficiency ${ }^{c}$ & 100 & 117.1 & 130.7 & 109.0 \\
\hline Feed cost (LE)/kg gain & 22.98 & 20.64 & 18.88 & 20.83 \\
\hline
\end{tabular}

$L E=$ Egyptian pound equals 0.11 USS approximately

a Based on prices of year 2019

bValue of 1-kg live body weight equals 60 LE (2019)

${ }^{\mathrm{C}}$ Assuming that the relative economic efficiency of control diet equals 100 
that the use of agro-industrial by-products in sheep rations has been successfully adopted as a strategy to reduce feeding costs and also to cope with the need to recycle waste material. Also, Romero-Huelva et al. (2012) noted that instead of $35 \%$ of concentrate with feed blocks containing waste fruits in lactating goat rations reduced animal feeding cost. Also, El Shaer et al. (1997) concluded that organic waste feed mixture used as non-conventional feed could be efficiently used as nutritious, palatable, and low-cost feed resources for small ruminants in Egypt.

\section{Conclusion}

From the data illustrated in the present study, it could be mentioned that dried pomegranate peel can be used safely in sheep feeding at level of $1 \%$ because this level realized the best growth performance and depressed the price of ration cost and recorded the best relative economical efficiency.

\begin{abstract}
Abbreviations
$\%$ : Percentage; ${ }^{\circ} \mathrm{C}$ : Degree centigrade; ADF: Acid detergent fiber; ADL: Acid detergent lignin; AOAC: Official Methods of Analysis; Ca: Calcium; CF: Crude fiber; CFM: Complete feed mixture; CP: Crude protein; Cu: Cobber;

DHA: Docosahexaenoic acid; DM: Dry matter; DMI: Dry matter intake;

DPP: Dried pomegranate peels; EE: Ether extract; EPA: Eicosapentaenoic acid; FAOSTAT-FAO: Statistical database. Food and Agriculture Organization of the United Nations; Fe: Iron; FW: Final weight; g/h/d: Gram per head per day; g/ kg: Gram per kilo gram; g/kgW ${ }^{0.75}$ : Gram per kilo gram metabolic body weight size; GE: Gross energy; K: Potassium (K); Kg/100 kg LBW: Kilogram per 100-kg live body weight; kg/ton: Kilogram per ton; LBW: Live body weight; LE: Egyptian pound; LE/ kg gain: Egyptian pound per kilogram gain; Mg: Magnesium; mg/100 g: Millegram per $100 \mathrm{~g} ; \mathrm{ml} / \mathrm{min}$ : Mille per minute; Mn: Manganese; MUFA: Monounsaturated fatty acids; Na: Sodium; NDF: Neutral detergent fiber; NFE: Nitrogen free-extract; NRC: National Research Council; P: Phosphorus; PUFA: Polyunsaturated fatty acids; Se: Selenium; SEM: Standard error of the mean; SFA: Saturated fatty acids; SPSS: Statistical package for Social Sciences; TBWG: Total body weight gain; TUFA: Total unsaturated fatty acids; Vit: Vitamin; Vit. A: Retinol; Vit. $B_{1}$ : Thiamine; Vit. E: a-Tochoferol; Vit. B2: Riboflavin; Vit. C: L-Ascorbic acid; Zn: Zinc; a-Linolenic: Alpha linolenic; $\mu$ : Overall mean; $\omega-3$ : Omega three; $\omega-6$ : Omega six; $\omega 6 / \omega 3$ : Omega six/Omega three; $\omega 7$ : Omega seven; $\omega-9$ : Omega nine
\end{abstract}

\section{Acknowledgements}

Our deep thanks for the workers in the Sheep and Goats' Units for their help in conducting follow-up on the experimental animals during the feeding trial and cooperating in many steps that make this work possible.

\section{Authors' contributions}

HAAO cooperated in the plane of work, field work, chemical analysis, arrangement data, statistical data, and writing, corrected the MS, and helped in the publication. SSA cooperated in the plane of work, field work, and following publication with the Journal (corresponding author). IMA cooperated in the plane of work, field work, and revision of the MS. All authors read and approved the final manuscript.

\section{Funding}

All authors equally shared in financing the cost of the research paper.

\section{Availability of data and materials}

"Not applicable" for that section.

Ethics approval and consent to participate

"Not applicable" for that section.

\section{Consent for publication}

"Not applicable" for that section.

\section{Competing interests}

The authors declare that they have no competing interests.

Received: 20 August 2019 Accepted: 29 November 2019

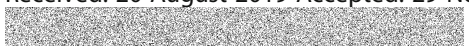

\section{References}

Abbasi H, Rezaei K, Emamdjomeh Z, Mousavi SME (2008b) Effect of various extraction conditions on the phenolic contents of pomegranate seed oil Eur. J Lipid Sci Technol 110:435-440

Abbasi H, Rezaei K, Rashidi L (2008a) Extraction of essential oils from the seeds of pomegranate using organic solvents and supercritical CO2. J Amer Oil Chem Soc 85:83-89

Abdel-Rahim EA, El-Beltagi HS, Romela RM (2013) White bean seeds and pomegranat peel and fruit seeds as hypercholesterolmic and hypolipidemic agents in albino rats. Grasas Aceites 64(1):50-58

Adams LS, Seeram NP, Aggarwal BB, Takada Y, Sand D, Heber D (2006) Pomegranate juice, total pomegranate ellagitannins, and punicalagin suppress inflammatory cell signaling in colon cancer cells. J Agric Food Chem 54:980-985

AOAC (2000) Method 969.33. Official Methods of Analysis. 17. AOAC Int., Washington, DC

AOAC (2005) Official Methods of Analysis, 18 Association of Official Analytical Chemists, Washington, DC

Aviram M, Dornfeild L, Rosenblat M, Volkova N, Kaplan M, Coleman R, Hayek T, Presser D, Fuhrman B (2000) Pomegranate juice consumption reduces oxidative stress, atherogenic modifications to $L D L$, and platelet aggregation: studies in humans and in atherosclerotic apolipoprotein E-deficient mice. Am J Clin Nutr 71:1062-1076

Aviram M, Dornfeld L, Kaplan M, Coleman R, Gaitini D, Nitecki S, Hofman A, Rosenblat M, Volkova N, Presser D, Attias J, Hayek T, Fuhrma B (2002) Pomegranate juice flavonoids inhibit low-density lipoprotein oxidation and cardiovascular diseases: studies in atherosclerotic mice and in humans. Drugs Exp Clin Res 28:49-62

Bampidis VA, Robinson PH (2006) Citrus by-products as ruminant feeds: a review. Anim Feed Sci Technol 128:175-217

Batta AK (1973) Rangaswami S 1973. Crystalline chemical components of some vegetable drugs. Phytochemistry 12(1):214-216. https://doi.org/10.1016/ S0031-9422(00)84654-3

Blaxter KL (1968) The energy metabolism of ruminants, 2nd edn. Charles Thomas Publisher. Spring field, Illinois, U.S.A.

Brown MW, Watkinson JH (1977) An automated fluorometric method for the determination of nanogram quantities of selenium. Anal Chem Acta 89: 29-35

Denek N, Can A (2006) Feeding value of wet tomato pomace ensiled with wheat straw and wheat grain for Awassi sheep. Small Rumin Res 65:260-265

Duncan DB (1955) Multiple rang and multiple F-test biometrics, 11: 1-42

El Shaer H, Kandil HM, Khamis HS, Abou El-Nasr HM (1997) Alternative feed supplement resources for sheep and goats in Egypt. In: Lindberg J.E, Gonda H.L, Ledin I. Recent advances in small ruminant nutrition. Zaragoza: CIHEAM, 93-97 (Options Méditerranéennes: Série A. Séminaires Méditerranéens, pp: 34

Elango S, Balwas R, Padma W (2011) Gallic acid isolated from pomegranate peel extract induces reactive oxygen species mediated apoptosis in A549 cell line. J Cancer Ther 2:638-645. https://doi.org/10.4236/jct.2011.25085

Elfalleh W, Hannachi H, Tlili N, Yahia Y, Nasri N, Ferchichi A (2012) Total phenolic contents and antioxidant activities of pomegranate peel, seed, leaf and flower. J Med Plants Res 6(1):4724-4730

Elfalleh W, Tlili N, Nasri N, Yahia Y, Hannachi H, Chaira N, Ying M, Ferchichi A (2011) Antioxidant capacities of phenolic compounds and tocopherols from Tunisian pomegranate (Punica granatum) fruits. J Food Sci 76(5):707-713

FAOSTAT-FAO (2010) Statistical database. Food and Agriculture Organization of the United Nations, Codex Alimentarius Commision: Tunis. http://www.fao. org

Hajimahmoodi M, Moghaddam G, Ranjbar AM, Khazani H, Sadeghi NM, Oveisi R, Jannat B (2013) Total phenolic, flavonoids, tannin content and antioxidant power of some Iranian pomegranate flower cultivars (Punica granatum L.). Am J Plant Sci 4:1815-1820. https://doi.org/10.4236/ajps.2013.49223 
Hajimahmoodi M, Oveisi MR, Sadeghi N, Jannat B, Hadjibabaie M, Farahani E, Akrami MR, Namdar R (2008) Antioxidant properties of peel and pulp hydro extract in ten Persian pomegranate cultivars. Pak J Biol Sci 11(12):1600-1604. https://doi.org/10.3923/pjbs.2008.1600.1604

Huxley RR, Neil H (2003) The relationship between dietary flavonol intake and coronary heart disease mortality: a meta-analysis of prospective cohort studies. Europ J Clinical Nutr 57:904-908

Jami E, Shabtay A, Nikbachat M, Yosef E, Miron J, Mizrahi I (2012) Effects of adding a concentrated pomegranate-residue extract to the ration of lactating cows on in Vivo digestibility and profile of rumen bacterial population. J Dairy Sci 95:5996-6005

Jayaprakasha GK, Negi PS, Jena BS (2006) Antimicrobial activities of pomegranate. In: Seeram NP, Schulman RN, Heber D (eds) Pomegranates: ancient roots to modern medicine. CRC Press, Taylor \& Francis Group, Boca Raton, pp 3-29

Kotsampasi B, Christodoulou V, Zotos A, Liakopoulou-Kyriakides M, Goulas P, Petrotos K, Natas P, Bampidis VA (2014) Effects of dietary pomegranate byproduct silage supplementation on performance, carcass characteristics and meat quality of growing lambs. Anim Feed Sci Technol 197:92-102

Kraul M (1966) Semi-automated determination of phospholipid. Clin Chem Acta 13:442-446

Kushwaha SC, Bera MB, Kumar P (2013) Nutritional composition of detanninated and fresh pomegranate peel powder. IOSR J Environ Sci Toxicol Food Technol (IOSR-JESTFT) 7(Issue 1):38-42

Lansky EP, Newman RA (2007) Punica granatum (pomegranate) and its potential for prevention and treatment of inflammation and cancer. J Ethnopharmacol 109(2):177-206

Leth T, Sondergaro H (1983) Biological activity of all-trance tocopherol determined by three different rat bioassays. Int J Vit Nutr Res 53:297-311

Li Y, Guo C, Yang J, Wei J, Xu J, Cheng S (2006) Evaluation of antioxidant properties of pomegranate peel extract in comparison with pomegranate pulp extract. Food Chem 96:245-260

Metche M, Nasr CB, Ayed N (1996) Quantitative determination of the polyphenolic content of pomegranate peel. Z Lebensm Unters Forsch 203: 374-378

Millipore Cooperative (1987) Liquid chromatographic analysis of amino acids in food using a modification of the PICO-TAG method

Noda Y, Kaneyuki T, Mori A, Packer L (2002) Antioxidant activities of pomegranate fruit extract and its anthocyanidins: delphinidin, cyanidin and pelargonidin. J Agric Food Chem 50(1):166-171. https://doi.org/10.1021/jf0108765

NRC (1985) Nutrient requirements of sheep, 6th edn. National Research Council, National Academy Press, Washington, DC

Omer HAA, Abdel-Magid Soha S (2015) Incorporation of dried tomato pomace in growing sheep rations. Glob Vet 14(1):01-16

Reed JD (1995) Nutritional toxicology of tannins and related polyphenols in forage legumes. J Anim Sci 73:1516-1528

Romero-Huelva M, Ramos-Morales E, Molina-Alcaide E (2012) Nutrient utilization, ruminal fermentation, microbial abundances and milk yield and composition in dairy goats fed diets including tomato and cucumber waste fruits. J Dairy Sci 95:6015-6026

Rosenblat M, Aviram M (2006) Antioxidative properties of pomegranate: in vitro studies. In: Seeram NP, Schulman RN, Heber D (eds) Pomegranates: ancient roots to modern medicine. CRC Press, Taylor \& Francis Group, Boca Raton, pp 31-44

Rowayshed G, Salama A, Abul-Fadl M, Akila-Hamza S, Mohamed EA (2013) Nutritional and chemical evaluation for pomegranate (Punica granatum L.) fruit peel and seeds powders by products. Middle East J Appl Sci 3(4):169-179

Sadq SM, Ramzi DOM, Hamasalim HJ, Ahmed KA (2016) Growth performance and digestibility in Karadi lambs receiving different levels of pomegranate peels. Open J Anim Sci 6:16-23

Shabtay A, Eitam H, Tadmor Y, Orlov A, Meir A, Weinberg P, Weinberg ZG, Chen Y, Brosh A, Izhaki I, Kerem Z (2008) Nutritive and antioxidative potential of fresh and stored pomegranate industrial byproduct as novel beef cattle feed. J Agric Food Chem 56:10063-10070

Singleton VL, Orthofer R, Lamuela-Raventos RM (1999) Analysis of total phenols and other oxidation substrates and antioxidants by means of folinciocalteu reagent. Methods Enzymol 299:152-178

SPSS (2008) Statistical package for Social Sciences, Statistics for Windows, Version 17.0. Released 2008. Chicago: SPSS Inc.
Wang ML, Wang JT, Choong YM (2004a) A rapid and accurate method for determination of methanol in alcoholic beverage by direct injection capillary gas chromatography. J Food Compos Anal 17:187-196

Wang RF, Xie WD, Zhang Z, Xing DM, Ding Y, Wang W, Ma C, Du LJ (2004b) Bioactive compounds from the seeds of Punica granatum (pomegranate). J Nat Prod 67:2096-2098

\section{Publisher's Note}

Springer Nature remains neutral with regard to jurisdictional claims in published maps and institutional affiliations.

\section{Submit your manuscript to a SpringerOpen ${ }^{\circ}$ journal and benefit from:}

- Convenient online submission

- Rigorous peer review

- Open access: articles freely available online

- High visibility within the field

- Retaining the copyright to your article

Submit your next manuscript at $\boldsymbol{\nabla}$ springeropen.com 